This is a self-archived version of an original article. This version may differ from the original in pagination and typographic details.

Author(s): Heikka, Johanna; Halttunen, Leena; Waniganayake, Manjula

Title: Perceptions of early childhood education professionals on teacher leadership in Finland

Year: 2018

Version: Accepted version (Final draft)

Copyright: ㅇ 2016 Informa UK Limited, trading as Taylor \& Francis Group.

Rights: In Copyright

Rights url: http://rightsstatements.org/page/InC/1.0/?language=en

Please cite the original version:

Heikka, J., Halttunen, L., \& Waniganayake, M. (2018). Perceptions of early childhood education professionals on teacher leadership in Finland. Early Child Development and Care, 188(2), 143156. https://doi.org/10.1080/03004430.2016.1207066 


\title{
Perceptions of Early Childhood Education Professionals on Teacher Leadership in Finland
}

\author{
Heikka Johanna*
}

School of Applied Educational Science and Teacher Education, University of Eastern

Finland, Savonlinna, Finland, University of Eastern Finland, Savonlinna campus,

Kuninkaankartanonkatu 7, PL 86, 57101 Savonlinna**, Phone: +358 (0)294 451111

\section{Halttunen Leena}

Department of Education, Institute of Educational Leadership, University of Jyväskylä, Jyväskylä, Finland, PL 35, 40014, University of Jyväskylä, Finland, Phone:

+358504413677,Email:leena.halttunen@jyu.fi

\section{Waniganayake Manjula}

Institute of Early Childhood, Macquarie University, Sydney, Australia, Institute of Early Childhood, Macquarie University, NSW 2109, Australia, Phone: +61 298509825

Email: manjula.waniganayake@mq.edu.au

*Corresponding author. Email: johanna.heikka@uef.fi

**The affiliation where the research was conducted

Johanna Heikka, $\mathrm{PhD}$, is a Senior Lecturer at the School of Applied Educational Science and Teacher Education at University of Eastern Finland in Savonlinna, Finland. Her current research projects focus on teacher leadership and distributed leadership in early childhood education.

Leena Halttunen, $\mathrm{PhD}$, is a University Teacher at the Institute of Educational Leadership at University of Jyväskylä in Jyväskylä, Finland. Her current research is focusing on distributed leadership and on early childhood education teachers' leadership positions.

Manjula Waniganayake, $\mathrm{PhD}$, is a Professor of Early Childhood at the Institute of Early Childhood at Macquarie University in Sydney, Australia. The research monograph Thinking and Learning about Leadership: Early childhood research from Australia, Finland and Norway, published in 2015 , reflects her global interests in early childhood policy and practice. 


\title{
Perceptions of Early Childhood Education Professionals on Teacher Leadership in Finland
}

\begin{abstract}
This study investigated perceptions of early childhood education (ECE) professionals employed at three ECE centres on teacher leadership enactment in Finland. Theoretically, the study was anchored on teacher leadership (Fairman \& MacKenzie, 2014; Harris, 2003; 2005; York-Barr \& Duke, 2004) and distributed leadership (Heikka, 2014; Mascall, Lethwood, Traus, \& Sacks, 2008). Findings suggest that teacher leadership was perceived as a responsibility of ECE pedagogy. Centre directors were considered remote from daily practice and leadership for pedagogy was shared with teachers. Teacher leadership was enacted through assessment, planning and ensuring that pedagogy was connected with each centre's goals. Centres differed on how they perceived support was provided for teachers.
\end{abstract}

Keywords: early childhood education; leadership; teacher leadership; leadership perceptions; team

\section{Introduction}

In this study the perceptions of early childhood education (ECE) professionals on teacher leadership were investigated. These professionals comprised childcare nurses, teachers and directors employed in ECE centres in Finland. Theoretically, the study was anchored in a review of scholarly literature on teacher leadership (eg. Fairman \& MacKenzie, 2012; 2014; Harris, 2003; 2005; York-Barr \& Duke, 2004) and distributed leadership (eg. Heikka, 2014; Mascall, Lethwood, Traus, \& Sacks, 2008). Staff employed in three ECE centres from different municipalities in Finland, participated in this study as a purposive sample for data collection. In each centre, one team, including the director, participated in the individual interviews conducted for this research. The analysis of data collected indicated that ECE teacher leadership was perceived as a pedagogical responsibility. Teacher leadership was considered essential especially because centre directors were 
perceived as being remote from daily practice. The perceptions about how teacher leadership was enacted included assessment, planning and ensuring that pedagogy was connected with the ECE goals at each centre. In addition, teacher leadership was perceived as sharing pedagogical leadership with the centre director and teachers from other groups. The centres differed in terms of how they perceived support was provided for the teachers.

According to the Organisation for Economic Co-operation and Development's (OECD) policy profile for Finland (Taguma, Litjens, \& Makowiecki, 2012) the strength of the Finnish ECE system rests on the employment of well-educated, and well-trained, multi-disciplinary staff. These staff work as small teams with qualifications from diverse disciplines. To work as ECE teachers, they are required to have a Bachelor of Education degree from a university (International Standards Classification for Education [ISCED] 6) or a Bachelor of Social Services degree from a University of Applied Sciences (ISCED 6). Additional staff members in a team are required to have completed a vocational qualification in social welfare and/or health care and could include for example, a practical nurse, with an upper secondary education (ISCED 3) (cf. Act on Qualification Requirements for Social Welfare Professionals 272/2005, section 7 and 8).

Contemporary discussions in Finland emphasise ECE teachers' role as the most pedagogically qualified professionals in centres, and as the pedagogical experts they have a great deal of autonomy. ECE teachers' expertise is connected with their education, research and developmental skills (Varhaiskasvatuksen henkilöstön koulutus ja osaaminen, 2007). The importance of the teachers' role is also connected with the administrative changes within municipalities because most centre directors are now expected to lead several centres simultaneously (Halttunen, 2009). At the same time, the number of ECE teachers in Finland has decreased: at the national level, only 24.4 per cent of the ECE workforce were employed as ECE teachers and held a pedagogical qualification from higher education. Another 39.1 per cent of the workforce were employed as childcare nurses with a vocational education certificate. It is also more common to employ a social pedagogue, who is a graduate from a university of Applied Sciences due to the shortage of university trained ECE teachers (Alila et al., 2014).

Within this context, teachers are expected to provide ECE pedagogical expertise to around 70 per cent of centre staff from diverse disciplinary backgrounds other than ECE. Taking into account these contextual circumstances, recent discussions and theorising of ECE practice have been emphasising the importance of the role of ECE teachers as 
pedagogical leaders within multi-professional teams (Heikka, 2014). Accordingly, the enactment of leadership by ECE teachers in Finland involves leading staff teams with a mix of professionals with or without ECE disciplinary knowledge.

School education scholars have recognised the importance of teacher leadership for several decades. During the past two decades scholars have explored teacher leadership under at least four conceptualisations: participatory leadership, leadership as an organisational quality, distributed leadership and parallel leadership (York-Barr \& Duke, 2004). This study explores teacher leadership within the framework of distributed leadership by proposing that the two concepts of distributed leadership and teacher leadership are intertwined. Connections between these two concepts have been made previously, for example by Harris $(2003 ; 2005)$ in school leadership research, and by Ho (2012) in ECE leadership research. Harris (2003) suggested that 'teacher leadership is conceptually closely linked to distributive leadership, but is narrower, being concerned exclusively with the leadership roles of teaching staff' (p. 112-113).

Distributed leadership builds upon the idea that leadership is socially constructed (Harris, 2003). This means that leadership is a continuous process of shared meaning making by members of the organisation. It includes the development of organisational goals, values, creation of new information and learning activities. The conception of leadership as distributed can enhance the growth of teacher leadership. The concept of distributed leadership is best understood as a practice 'distributed over leaders, followers, and the school's situation or contexts' (Spillane, Halverson, \& Diamond, 2004, p.11). Interdependence between people and their enactments of leadership is a core element of implementing distributed leadership (Harris, 2009; Spillane, Halverson, \& Diamond, 2001). Practising distributed leadership seems to be connected with planning leadership enactment and dependent on the active engagement of leaders (Harris, 2008; MacBeath, 2005; Mascall et al., 2008; Muijs \& Harris, 2007).

Research suggests that distributed forms of leadership have significant impact on the achievement of outcomes for a group or an organisation such as a school or an ECE setting (Gronn, 2000; Harris, 2009; Spillane et al., 2001). Heikka, Waniganayake, and Hujala (2013) have reviewed research that suggests that distributed leadership has positive impacts on teachers, leaders and on education itself. These conditions are achieved when distributed leadership is well managed, goal oriented, planned and developed continuously. The involvement of all organisational levels and support from different stakeholders was also shown to be essential. 
However, research on the impact of distributed leadership on organizational improvements is rare (Harris, Leithwood, Day, Sammons, \& Hopkins, 2007). Some studies conducted within school contexts by those such as Camburn and Han (2009), Firestone and Martinez (2007), Leithwood et al., (2007) and Timperley (2005), indicate positive impact of distributed forms of leadership in realising organisational goals. In comparison, distributed leadership research conducted in ECE contexts is relatively scant and small scale (Colmer, Waniganayake, \& Field, 2015; Heikka, 2014).

Likewise, empirical studies focusing on teacher leadership have been conducted primarily within school contexts (see Harris, 2005; York-Barr \& Duke, 2004). Having reviewed 140 leadership studies, York-Barr and Duke (2004) declared that teachers are increasing their leadership functions both at the pedagogical and organisational levels. This research suggests that teacher leadership is connected with the belief that all organisational members can lead and that leadership is a form of agency that can be distributed. Several researchers (such as, Fairman \& Mackenzie, 2015; Smylie \& Mayrowetz, 2009) remind us that teacher leadership may be either a formal or informal role. According to Fairman and Mackenzie (2015) teachers in their research emphasized informal leadership activities and relationships. The key functions of a teacher leader are to develop the organisation by promoting the achievement of its organisational goals. This could consist of facilitating, influencing others and participating in decision making by teacher leaders. An important notion of teacher leadership enactment is that teachers' influence extends beyond their classrooms (Emira, 2010; Frost, 2008).

Fairman and Mackenzie (2015) also refer to teachers' actions like modelling professional attitudes, coaching colleagues, collaborating with colleagues and advocating for change. Teacher leadership means that teachers have agency to lead change and to guide organisational development and improvement. Teacher leaders motivate colleagues towards change and organisational goals, they promote pedagogical improvement within their multi-professional teams, lead curriculum work and support others in their efforts to achieve pedagogical improvement (Harris, 2003). Fairman and Mackenzie (2015) expanded York-Barr and Duke's framework and acknowledged teacher leadership activities both at the individual and at collective levels. Teacher leadership could also mean managing a process of change and guiding and motivating others to engage in professional development (Danielson, 2003). Several studies (eg. Firestone \& Martinez, 2007; Harris, 2008; Mascall et al., 2008; Muijs \& Harris, 2007) indicate that functioning of distributed leadership amongst teachers requires pedagogical expertise, continuous 
development of leadership, planning, trust, and co-operation. Additionally, organisational structures, including a shared vision, and support from administrative staff were also shown to be crucial.

Nevertheless, part of the discussion concerning teacher leadership also reminds us about the pitfalls and challenges. Smylie and Mayrowetz (2009) identified five footnotes as critical issues that may be overlooked or taken-for-granted: i) teacher leadership is simply a label for good leadership; ii) a good teacher is not automatically a good leader; and iii) teacher leaders may alter their collegial relationships when accepting a leadership position in the same organisation; iv) the administrative leaders' support is needed as well as v) the need to discuss who in the end is the leader, because everyone should be seen as a leader. Fairman and Mackenzie (2015) also express similar reservations that teacher leaders may face challenges in building trust among their colleagues, break the autonomy of teachers, and take risks in changing practice; and all of these elements are connected with establishing their own leadership identity.

Recent studies by Colmer (2015), Ho (2010; 2011; 2012), Hognestad and Boe (2014; 2015) have increased our understanding of teacher involvement in leadership practices within ECE contexts. Norwegian researchers, Hognestad and Boe (2015) examined 'how social conditions shape the formal teacher leaders' leadership practices of site-based knowledge development' (p. 224) and found that teaching and leading functions were intertwined in every day practice. They also highlighted the importance of informal face-to-face interactions between teachers and other staff in knowledge development within the centre. This was reinforced by Colmer et al. (2015, p. 210), who reported that centre directors in Australia acknowledged that positional leaders were expected to support the professional development of their room staff and that this learning 'may occur informally' in day-to-day work. Colmer (2015), also found that 'Over time, the collective professional agency of the educators can modify organisational culture' (p.43) of ECE centres.

Based on research in Hong Kong, Ho (2010; 2011) connects teacher leadership with curriculum decisions made by teachers. She concludes that the role of the school principal in creating structures and enhancing culture is crucial in the development of teacher leadership (Ho, 2010). However, she also found that teachers themselves felt more as followers when leadership was mainly held by the principal (Ho, 2011). In reviewing literature on teacher leadership Ho and Tikly (2012) highlight the importance of addressing the applicability of constructions of teacher leadership in diverse political 
and cultural contexts, a view shared by Waniganayake (2014) who also notes social and economic constraints connected with external steering.

Research has consistently confirmed a strong association between staff' qualifications and quality provision of ECE (OECD, 2012, 2013; Sims \& Waniganayake, 2015; Waniganayake et al., 2012). It follows that university-qualified ECE teachers are well placed to promote pedagogical leadership at the team level as can be seen in Australian ECE centres (Colmer et al., 2014; 2015). Highly efficient leadership occurs in centres where the stakeholders experience being valued as members of a team and can contribute to decision-making (Ebbeck \& Waniganayake, 2003; Rodd, 2013). Recent studies suggest that quality improvement in ECE settings are dependent not only on the qualifications of ECE teachers, but also their ability to take on leadership roles (Sims \& Waniganayake, 2015).

Inspired by the idea that all organisational members can lead, Heikka (2014) investigated the enactment of ECE leadership as distributed through organisational contexts in Finnish municipalities. Using this research, she developed the conceptual framework of distributed pedagogical leadership depicting the interdependence between the micro and macro level leadership enactments in pedagogical development. The core elements of distributed pedagogical leadership were identified as: multiple persons involved in leadership, the enactment of pedagogical leadership through ECE contexts, and interdependence in leadership enactments. In ECE organisations, distributed pedagogical leadership focuses on curriculum work and pedagogical improvement, which were enacted by ECE stakeholders working at the micro level as teachers and centre directors in ECE centres, and at the macro level of municipal organisations as ECE leaders and municipal committees.

Heikka (2014) identified five interdependent ways of enacting leadership tasks, functions and responsibilities which could be applied in implementing teacher leadership in ECE settings. First, enhancing shared consciousness of the vision and strategies between the stakeholders. Secondly, distributing responsibilities for pedagogical leadership. Thirdly, distributing and clarifying power relationships between the stakeholders. Fourthly, distributing the enactment of pedagogical improvement within the centres, and finally, developing strategy to enact distributed pedagogical leadership. Interdependence exists when the enactment of leadership functions, tasks and responsibilities by various leadership stakeholders are coordinated and focussed on achieving the shared goals of an ECE organisation as depicted in Heikka's study. 
Norwegian researchers have also extended the idea of distributed pedagogical leadership claiming that teacher leadership occurs as a hybrid form in ECE settings (Hognestad \& Boe, 2015). This hybrid conceptualisation emerged from the work of Gronn (2011) who first recognised that solo and distributed leadership can co-exist. As hybrid leaders, teacher leaders can make use of both formal and informal opportunities to support others in their organisations. In legitimising their positional authority as a teacher leader with their teams, Hognestad and Boe (2015) warn that this could also 'weaken teacher leaders' professionalism' especially if they were to 'adapt their professional language to match their assistant's everyday language' (p.11). The juggling acts performed by these teacher leaders are worthy of deeper analysis.

In Finland, there is much discussion and debate about the position of an ECE teacher as a pedagogical leader in their teams. This debate has been fuelled by the persisting culture of ECE practice called 'everybody does everything'. This reflects a sense of democracy or equality among ECE professionals, also found in childcare centres in Australia (Waniganayake, Morda, \& Kapsalakis, 2000). According to Alila et al. (2014), there is confusion about the leadership and power of ECE teachers in their classroom teams and the power of the ECE teachers across a centre may not always be recognized. For instance, teachers have reported that initiating change within their own classroom was easier rather than the centre as a whole (Grarock \& Morrissey, 2013). The reality of pedagogical decision-making within ECE centres, however, requires closer scrutiny as positional authority of a centre director can prevail and override decisions made by a small team within a classroom. Importantly, the concept of teacher leaders in relation to other position holders within a centre such as deputy directors, and beyond a centre such as an area manager or municipal leaders, requires further research.

\section{Aims of the Study}

This study investigated teacher leadership as perceived by ECE center directors, teachers and childcare nurses, working in three centres in Finland. Its significance is growing due to increasing interest in theorising and researching ECE leadership in general and distributed leadership research in particular. Also public discussions in Finland and elsewhere, such as Australia and Norway, emphasise teachers' professional expertise within ECE centres. Responsibility for pedagogy and knowledge development is connected with teachers' professional roles as identified in policy documents in Australia 
and Norway. In Finland, current ECE policy as well as administrative changes in municipalities have put pressure on teachers' pedagogical qualifications and the application of this expertise in ECE centres. Yet, teachers' work and professionalism are relatively under explored from the perspective of leadership. Two key research questions directed the study:

How is teacher leadership perceived by ECE professionals?

What kind of support is needed when enacting teacher leadership?

The findings can assist in clarifying the roles, responsibilities and division of labour among ECE professionals working in centre based teams as well as elsewhere in the municipality systems. All of this can support the development of leadership steering and functions in Finnish municipalities when leading and maintaining pedagogical quality within ECE organisations as well as in advancing ECE teacher education and ongoing professional learning for teachers.

\section{Study Methods}

Data collection was completed in 2015 and three ECE teams along with the centre directors from three municipalities were selected as a purposive sample for this study. The size of the municipalities was from around 35 000, 49000 and 112000 inhabitants representing typical Finnish medium to large towns. Municipal administrative ECE leaders recommended the centres and teams and data was collected through semistructured individual interviews. At each centre, members of one team, comprising an ECE teacher and two childcare nurses as well as the centre director, were involved in the data collection. In addition, in one centre there was a person whose position was identified as 'a pedagogical leader'. Her role in this research was deemed equal to a centre director while her duties included collaborating with the centre director to lead the pedagogy of the whole centre. This centre was specially asked to participate in the study because of the position of the pedagogical leader. The other two could have been any of the public centres of the municipality.

Each centre had 3-5 teams and in each team comprised a mix of ECE teachers and childcare nurses. In the smallest centre, there were 80 children and 14 staff members. In the biggest one, there were 190 children and 35 staff members. The three teams participating in the research, each consisted of one ECE teacher and two childcare nurses. 
There was no hierarchy among the teachers at the three centres. However, one of the teachers was a deputy director at her centre but this role is not a focus in this paper. In Finland, deputy directors do not usually lead pedagogy and their work usually focused on assisting the centre director in her/his administrative work.

In order to address the two key research questions of this study, three themes were formulated for the focus of this investigation: 'Pedagogical leadership', 'Roles and responsibilities of ECE professionals' and 'Support for ECE teacher leadership'. The first two themes were based in the ongoing discussion in Finland about the roles of different professionals and who is in charge of leading the pedagogy of a team. The third theme was based on the notions of how the leader's role is crucial in enacting distributed leadership. The interview questions focused, for example, on how pedagogical leadership was understood and perceived, how pedagogical leadership of an ECE teacher is different compared to centre director's, and what kind of support teachers get and need for their leadership. Interview questions were kept open enough to have space for centre and team specific themes to emerge. Open ended questions are also recommended if the study uses content analysis (Hsieh \& Shannon, 2005).

Overall, 13 individuals were interviewed once. All participants expect one were females and their work experience in ECE varied between two to 20 years. The role of the researcher was to organise the interviews together with the ECE leaders of the municipalities and inform the participants about the focus themes of the interview. During the interview the researcher asked questions and guided the discussion.

Issues covered during individual interviews were analysed through the application of qualitative content analysis. Content analysis is a method used with verbal, symbolic or communicative data (Krippendorff, 1980) and theoretical concepts and conclusions are generated through the process of interpretation and inference of participants' original expressions. According to Krippendorff (1980), when using content analysis, there are four steps in the research process: data making, data reduction, inference, and analysis.

In this study conventional content analysis was used in order to inductively form sub and main categories (Hsieh \& Shannon, 2005; Mayring, 2000). This inductive approach was used because only limited knowledge existed about the focus area of the study and provided access to "gaining direct information from study participants without imposing preconceived categories or theoretical perspectives." (Hsieh \& Shannon, 2005, pp. 1279-1280). The unit of analysis was a meaningful utterance, ranging from a couple of words up to a couple of sentences. Each interview and professional group was 
analysed separately in order to identify sub-categories that described the content of data in relation to the research aims and key questions. This made it possible to see if these professional groups had different or similar views. Themes were identified by reading the transcribed data and selecting for the expressions connected with the research questions. The three main themes identified previously in defining the interview questions, also guided the data analysis. Mayring (2000) emphasizes the step by step procedure in inductive content analysis: First, the themes emerging from the data for each professional group were compared to ascertain similarities and differences between the groups. Second, the utterances from different professional groups were combined. The clustering process led to the formulation of the sub-categories. Thirdly, the main categories of each data type were formulated based on the abstracting and combining of sub-categories. Too much abstraction was avoided so as to retain connection to the original content of the interviews.

\section{Key Findings}

The overarching finding of the study suggests that ECE teacher leadership was perceived as a responsibility of ECE pedagogy. Specifically, ECE teacher leadership at the team level comprised assessing, planning and ensuring that pedagogy was based on the organisational goals set at each centre. According to all the professionals participating in this research, the enactment of teacher leadership at the centre level included sharing pedagogical leadership between the centre director and teachers from various children's groups at the same centre. There were numerous similarities in perceptions held by these participants across the three centres about the perceived effectiveness and enactment of teacher leadership. The centres also differed on the conditions established to provide tangible support for the enactment of teacher leadership. The findings are arranged under three key themes, and participants' voices are used to illustrate their perspectives directly.

\section{ECE teacher leadership as a responsibility of ECE pedagogy}

According to the study participants, the responsibility for ECE pedagogy encompassed planning, assessing and aligning pedagogy with long term goals of the ECE centre 
specifically and the municipality, broadly. It also included directing teams as well as sharing responsibilities with team members in daily practice to satisfy centre goals.

All professional groups emphasised the significance of teacher leadership and perceived it to be effective in ensuring pedagogical quality. Teacher leadership was also perceived essential for children's learning and goal oriented pedagogy. The centre directors perceived teachers as pedagogical leaders and as links between them and the classroom teams. Centre directors believed that the director led the teams through the teachers. Both centre directors and teachers thought that the teachers' responsibilities were to ensure that quality criteria and goals set at the centre level were achieved.

The significance of ECE teacher education was emphasised by all participants. The teachers connected teacher leadership with decision-making about pedagogy and considered that it was important to bring knowledge gained in their education to guide team members. One centre director described teacher leadership as theoretical expertise, common knowledge, sensitivity and interest in children and adults. The childcare nurses perceived teacher leadership as important for the versatility and development of ECE pedagogy. Childcare nurses addressed the knowledge teachers have about child development and pedagogy as specialist knowledge unlike their own education which was more broadly based.

In addition, ECE teacher leadership was perceived essential especially because the centre directors were seen to be too remote from daily practice in leading pedagogy in the children's groups. As one director explained, her own work focused more on administration:

'I feel a bit afraid that I'm remote from my staff because I have so limited time to be in the groups and I don't see my staff so often. In the near future, I have a plan to be more in touch with the staff because I do not want to become an administrative 'oddity'. I don't want to become estranged and I want to know my staff.' (Centre director)

In one centre where the director had responsibilities at the municipality level, they had recruited a separate pedagogical leader. Such a position is rare in Finland. This pedagogical leader supported centre staff in pedagogical issues. The way support was offered varied. For example, she consulted the staff about the needs of individual children, she frequently joined team meetings or visited the teams both to observe the staff and the 
children and she was the chair of the professional group meetings. Importantly, the centre director said that she had the final leading role in the pedagogy at the centre.

Although teachers had the main responsibility for pedagogy, they did it in cooperation with their team members. There were also differences between the three centres on how childcare nurses perceived their role in relation to the teachers. In one team, both childcare nurses considered themselves to be assistants to the teachers in daily pedagogy. In another centre, the responsibility of daily pedagogy and activities was reported to be distributed among team members explicitly as children were divided into groups and nurses as well as the teacher guided children separately. Nevertheless, the teacher was responsible for some pedagogical functions and activities with all the children. It was also emphasised that the teacher should plan and be aware of the annual pedagogy for the whole child group.

'Although there is an agreement that a childcare nurse is responsible, for example, about PE, the ECE teacher has to know what kind of activities should take place and in that way has the final responsibility.' (Centre director)

The findings also showed that teacher leadership included mainly ECE curriculum functions which were enacted both at the centre and at the team level. This included participating in curriculum work and sharing pedagogical leadership at centre level with directors and other teachers in the centre, as well as aligning and directing curriculum processes at team level. There were different ways how teachers were involved in the pedagogical leadership at the centre level. In one centre, there was a clear structure with a coordinating group where teachers co-operated and shared curriculum work. According to the director and teachers in this centre, the shared curriculum work was enacted as assessment and development of pedagogy as well as developing ECE pedagogy. Teachers in this centre had specific responsibility for pedagogical development, for example, preschool education. The group met regularly and was chaired by the centre director.

In one centre, teachers built shared guidelines for pedagogy together with the centre director, pedagogical leader and other teachers. They had annual development days in addition to regular meetings involving all teachers at the centre, at least 4-5 times per year. The pedagogical leader chaired these meetings and the responsibility for planning them but it was open to all teachers to bring topics to the meetings. The childcare nurses also had their own meetings. The major pedagogical guidelines were agreed in these 
meetings (for example, dividing the child group into smaller groups for the daily activities) but the teachers had a lot of autonomy in planning the pedagogy of their own child group.

At the team level, there was a clear structure of weekly team meetings chaired by the ECE teacher. In this way teacher leadership was enacted in weekly team meetings. When one of the teams of a centre had a weekly team meeting other staff members took care of their children, for example, during the time when children rested. The focus of these meetings was to consider the short and long term pedagogical planning, assessment, and sharing knowledge about the children.

\section{Enacting teacher leadership}

The main leadership functions and tasks of the teachers at the team meetings consisted of pedagogical leadership, quality management and assessment as well as planning and organising the daily functions in a children's group within a centre. According to the centre directors, teacher leadership was enacted at the team level when a teacher brings the goals which were negotiated at centre level for the team and assisting team members to concretise the goals in planning the daily pedagogy of their children's group.

In addition, according to centre directors, teachers have to manage new guidelines set by law reforms as well as the national ECE curriculum framework. This involves a teacher assisting team members to think of what do the broad goals set for pedagogy of the whole centre mean for the pedagogy of an individual child in a group. The centre directors perceived that the teachers' responsibilities were to focus on the team structure and the development of the team's skills and understanding of pedagogy. An ECE teacher must be professionally and personally strong, understand working with people from diverse backgrounds and have good interpersonal skills. It was also considered important that a teacher can question the prevailing conceptions of ECE work and renew their knowledge base. Sharing responsibilities, leading the team and taking care of team members' professional knowledge and development were understood as the main leadership responsibilities of teachers. The director from Centre A summarized that teachers should

'...be able to be a good team leader, understand the strengths and weaknesses of the team members and take into account the current premises in the pedagogical planning, in 
addition to being aware of changing circumstances of families and society.' (Centre director)

ECE teachers considered that their responsibility was to take care of that team members' shared understanding of the roles, responsibilities and tasks as a team. They also perceived that their responsibility was to negotiate shared values and principles for ECE practice with the team. Teachers viewed their role and responsibility as a leader of the team who makes decisions for long and short term plans and guided and supported the team in such a way that the pedagogical quality was guaranteed. Guiding the team and providing feedback to childcare nurses and discussing problems as a team were considered important. However, one of the teachers felt inadequate in pedagogical leadership because of the increased amount of administrative duties. Other teachers said that there was and has to be mutual respect between different professionals and commitment to the agreements made together. She said that it was also her responsibility to give opportunities to childcare nurses to bring their best to their work:

'Childcare nurses expect from us teachers a clear structure and that we know about the development and growth of children and that we work for the children's best. They expect us to be teammates, plan activities and them to be possible to do things where they are good and strong and us [teachers] to respect it.' (ECE teacher)

Childcare nurses also perceived that teachers should support them, discuss and guide their pedagogical practices as well as promote team skills and competencies. Guiding the team on a daily basis, respecting personal values and ways of working with children and bringing contemporary topics into discussion were all considered important. Childcare nurses also felt that teachers had more knowledge about the needs of children and the different qualifications held by staff members provided diversity in skills and knowledge for enacting pedagogy. They also considered that it was important to share responsibilities between the team members and acknowledged and development of team members' skills in this way:

'[pedagogical leadership] means that one is able to share responsibilities in a way that it is not wholly a task of a teacher but one can tap what childcare nurses and other teachers can do.' (Childcare nurse) 
Childcare nurses believed that ECE teachers enhanced nurses' participation in pedagogical planning through listening to their ideas. They also considered that teachers were responsible for the functioning of the children's groups. According to the nurses, an ECE teacher plans a broad framework for pedagogy, commits team members for shared planning, clarifies the responsibility areas and enriches team members' pedagogical work with children. They emphasized the teacher's responsibility for the content and functioning of pedagogy; however, at the same time, they expected opportunities to present their own ideas.

According to all professional groups, ECE teachers' responsibilities included cooperation with parents and organizing and conducting the ECE curriculum discussions with parents. ECE teachers perceived that taking responsibility for individual children's learning and development and making individual plans both for children with parents and for a children's group were the most important parts of their role as a teacher leader.

All professional groups also perceived that organizing and conducting weekly team meetings was an important task of a ECE teacher. According to the team members, teachers functioned as a chair in the team meetings and according to the teachers, they also took care of the team contracts at the beginning of each year. In a team contract, team members, for example, agreed on the work duties and tasks of each team member.

\section{Support from different ECE leadership stakeholders considered crucial}

The centres differed in relation to how the support provided for enacting teacher leadership was perceived. In one centre a specific position called a pedagogical leader had been established to support ECE teachers in their work. At another centre, there was a specific structure for peer support amongst teachers. In the other centre, the ECE teacher felt that the established forum for teachers was insufficient for supporting pedagogical leadership because the discussion in the group was not focused on pedagogical assessment and long term planning. This view was also confirmed by the other participants from this centre. They perceived that the director was too remote from the field to guide and ensure conditions for teacher leadership in centres.

The support from ECE centre directors and the other team members for ECE teachers was considered crucial by all the professional groups participating in this study. These teachers perceived that the presence of a centre director in daily ECE work was important, although this did not mean that the director must be present and work with 
children or staff at the centre every day. The support from centre directors included promotion of teachers' professional identity, clarifying the responsibility areas and job descriptions of ECE staff, sharing information, guiding curriculum work in the teams and aligning pedagogical development areas with the teachers in a centre.

'Jane [centre director] has very clearly said what are the responsibilities and tasks of teachers and what then belong to childcare nurses.' (ECE teacher)

ECE centre directors, teachers and childcare nurses emphasized the centre director's role in building the structures for curriculum work, establishing peer support groups for teachers, providing a framework and steering pedagogical development in a centre. Guiding the organisational culture and team work within a centre and improving the skills of individual staff were considered crucial. Centre directors and teachers emphasized also organization of work shifts, routines, weekly meetings and training as important supports for teacher leadership.

One director declared that her role as a pedagogical leader already starts when recruiting staff because it was important to clarify the pedagogical demands set for a teacher from the beginning. Another director considered clarifying and describing pedagogical development processes for the teams to guide them in organising planning and assessment. Usually, once a year, a development discussion was held between the director and the team and informal meetings were also held occasionally. The pedagogical leader interviewed explained that her support for teachers consisted mainly of being present in daily pedagogy and in providing support for child observations, assessment, planning and evaluation. Because she was present at the centre, she could also meet staff spontaneously.

Novice teachers in particular, emphasised the significance of peer support from colleagues working at the same centre. Peer support was enacted through the professional meetings and discussions among teachers. Teacher's personality and professional expertise were also considered important for the successful implementation of teacher leadership. Both teachers and childcare nurses emphasized the need for teachers to have leadership skills. If leadership is understood as being happy or weak as a leader, the whole pedagogy fails to be developed with a goal-oriented focus.

Directors also emphasised support provided by the municipality ECE leader comprising of valuing the ECE profession, demanding high quality performance, 
describing and clarifying staff' responsibilities and tasks and providing sufficient resources for pedagogical planning. The childcare nurses brought up the significance of local municipal ECE curricula for ECE teacher leadership ${ }^{1}$. Support from the municipality concretized teacher leadership by providing teachers planning time, available at the centre during work hours. Generally, however, pedagogical planning made by ECE teachers was not well organised as teachers lacked sufficient time and space to do individual pedagogical planning adequately. The ECE teachers' trade union and its promotion of ECE pedagogy was also mentioned by one teacher interviewed and information steering at the nation level was considered important.

Childcare nurses emphasized the support they could give to an ECE teacher. Some of the nurses discussed the meaning of their own attitudes towards their work. As one nurse explained, they needed to be ready to co-operate with the teacher and 'give the teacher a freedom to be a teacher and teach.' (Childcare nurse A). In addition, if there was a team contract it was perceived as an important document guiding the work in a team.

\section{Discussion}

The findings showed that the three ECE teachers participating in the study were leaders of their teams and their team members also expected leadership from them. Childcare nurses expected that the teacher sets the goals and plans the daily activities of their child group. However, based on the analysis, their leadership focused on short term planning and supporting team members in their daily tasks. The culture of "everybody does everything' was replaced with a strong demand for leadership from the childcare nurses and with an understanding from the teachers that the ECE teacher is the one who should lead the team.

At the centre level, leadership of the teachers was weaker. In each centre there was a different kind of development days and professional group meetings but these were mainly chaired by the centre director. In one centre, teachers had more centre-based pedagogical responsibilities but in the other two, their participation was more

\footnotetext{
${ }^{1}$ In Finland, all the municipalities have a curriculum based on the national guidelines. Each centre makes their own curriculum based on these documents.
} 
cooperative. The interdependence between the levels was however not very clear (cf. Heikka, 2014). It seems that the teacher leadership and autonomy of the ECE teachers was strong at the team level and at the centre level, and the directors lead pedagogy. Nevertheless, ECE teachers were expected to bring the municipality and centre level goals into practice at the team level.

Expectations of ECE teacher leadership in this study reflect the findings of Fairman and Mackenzie (2015). These findings also align well with the findings about roles and responsibilities of teacher leadership as noted by Firestone and Martinez (2007) and Harris (2008). In the Finnish context there is still, however, a lack of realizing the official leadership role of the ECE teachers and how they should be educated into this role. In analyzing research based on the work of educational leaders in Australia, Waniganayake (2015, p.12) comments that not having an official definition of the role of an educational leader can be perceived "as an opportunity for innovation". However, she adds that it can also lead to confusion and concern as centres try to separate and prioritise pedagogical roles against operational and administrative responsibilities within centres.

This study also reflects the tension between teacher leadership and director leadership found by Colmer et al. (2015) as well as Boe and Hognestad (2014). The extent to which this study supports the assertion by Colmer (2015) that 'lower director presence was associated with less cohesion among educators' (p.41) is however difficult to assess. It is nevertheless clear that these studies indicate that both formal and informal interactions between ECE professionals within centres can influence professional relationships, organisational culture and pedagogical decision-making across the system and occurring at team, centre and municipal levels. The application of teacher leadership in advancing pedagogy may be also supported or constrained by local structural factors including time available, staff numbers and qualifications at each centre. Additional research with longitudinal designs are necessary to investigate the veracity of impact of these factors on enacting pedagogical leadership with the aim of improving children's learning outcomes.

It is also evident that Finnish ECE teachers work in an unclear leadership position although their role as teacher leaders have been emphasized. Alila et al. (2014) in their report on Finnish ECE note that quite often only one professional out of three team members have a pedagogical education and therefore can perform pedagogical responsibilities. However, their positional power and leadership is not yet officially recognized. That is, in Finland, at present, ECE teachers' agency to act as leaders is 
limited and unclear. Alila et al. (2014), for example, emphasise the need to clarify the roles and responsibilities of different professional groups. As has been found in Australia, official recognition of teacher leadership is important in enabling ECE teachers to feel comfortable in providing "guidance or mentoring support to colleagues in the centre" (Waniganayake, 2015, p.13), especially in relation to enacting pedagogical responsibilities across the centre.

In Finland, there is also a lack of national level steering on how ECE teacher leadership should be enacted. To date, recognition and support for teacher leadership is with the municipality, or at the employer level, and at the centre level. Findings of this study highlight the importance of directors making visible expectations of teachers, especially their leadership responsibilities in their teams. Professional development programs can redress criticism of the participants in this study that centre meetings did not focus sufficiently on pedagogical issues. Likewise, the appointment of a centre based pedagogical leader who can provide more substantive support for teachers as well as other professionals and to create the pedagogy for the whole centre, requires further research.

Acknowledgements: This work was supported by the Finnish Cultural Foundation under Grant

Disclosure statement: No potential conflict of interest was reported by the authors.

\section{References}

Act on Qualification Requirements for Social Welfare Professionals 272/2005. Retrieved from http://www.finlex.fi/en/laki/kaannokset/2005/en20050272.

Alila, K., Eskelinen, M., Estola, E., Kahiluoto, T., Kinos, J., Pekuri, H.-M., Polvinen, M., Laaksonen, R., \& Lamberg, K. (2014). Varhaiskasvatuksen historia, nykytila ja kehittämisen suuntalinjat. Tausta-aineisto varhaiskasvatusta koskevaa lainsäädäntöä valmistelevan työryhmän tueksi. Opetus- ja kulttuuriministeriön työryhmämuistioita ja selvityksiä [The history, presence and the directions for the future development. The background information for the Early Childhood Eucation Act Working Committee] 2014, 12.

Camburn, E. M., \& Han, S. W. (2009). Investigating connections between distributed leadership and instructional change. In A. Harris (Ed.), Distributed leadership. Different perspectives (pp. 25-45). Dordrecht: Springer.

Colmer, K. (2015). Leading professional development and learning in early childhood centres: A social systems perspective. In M. Waniganayake, J. Rodd, \& L. Gibbs (Eds.), Thinking and learning about leadership. Early childhood research from 
Australia, Finland and Norway (pp. 32-48). Sydney: Community Child Care Cooperative (NSW).

Colmer, K., Waniganayake, M., \& Field, L. (2014). Leading professional learning in early childhood centres: Who are the educational leaders? Australasian Journal of Early Childhood, 39(4), 103-113.

Colmer, K., Waniganayake, M., \& Field, L. (2015). Implementing curriculum reform: Insights into how Australian early childhood directors view professional development and learning. Professional Development in Education, 41, 203-221. doi: 10.1080/19415257.2014.986815.

Danielson, C. (2003). Teacher leadership that strengthens professional practice. Alexandria, VA: Association for Supervision and Curriculum Development.

Ebbeck, M., \& Waniganayake, M. (2003). Early childhood professionals: Leading today and tomorrow. Sydney. MacLennan + Petty.

Emira, M. (2010). Leading to decide or deciding to lead? Understanding the relationship between teacher leadership and decision making. Educational Management, Administration \& Leadership, 38, 591-612. doi:10.1177/1741143210373738

Firestone, W.A., \& Martinez, M. C. (2007). Districts, teacher leaders, and distributed leadership: Changing instructional practice. Leadership and Policy in Schools, 6(1), 3-35. doi: 10.1080/15700760601091234.

Fairman, J. C., \& Mackenzie, S. V. (2012). Spheres of teacher leadership action for learning. Professional Development in Education, 38, 229-249. doi: 10.1080/19415257.2012.657865

Fairman, J. C., \& Mackenzie, S. V. (2015). How teacher leaders influence others and understand their leadership. International Journal of Leadership in Education, 18(1), 61-87. doi: 10.1080/13603124.2014.904002

Frost, D. (2008). 'Teacher leadership': values and voice. School Leadership and Management, 28, 337-352. doi: 10.1080/13632430802292258

Grarock, M. \& Morrissey, A-M (2013). Teachers' perceptions of their abilities to be educational leaders in Victorian childcare settings. Australasian Journal of Early Childhood, 38(2), June, 4-12.

Gronn, P. (2011). Hybrid configurations of leadership. In A. Bryman, D. Collinson, K. Grint, B. Jackson, \& M. Uhl-Bien (Eds.), The SAGE handbook of leadership (pp. 437-454). London: SAGE Publications Ltd. sẹ.

Gronn. P. (2000). Distributing properties: A new architecture for leadership. Educational Management, Administration and Leadership, 28, 317-338. doi:10.1177/0263211X000283006

Halttunen, L. (2009). Päivähoitotyö ja johtajuus hajautetussa organisaatiossa. [Daycare work and leadership in a distributed organization] Jyväskylä Studies in Education, Psychology and Social Research 375. University of Jyväskylä, Finland.

Harris, A. (2003). Teacher leadership as distributed leadership: Heresy, fantasy or possibility. School Leadership \& Management, 23, 313-324.

Harris, A. (2005). Teacher leadership: More than just a feel-good factor? Leadership and policy in schools, 4, 201-219. doi: 10.1080/15700760500244777

Harris, A. (2008). Distributed leadership: According to the evidence. Journal of Educational Administration, 46(2), 172-188. Retrieved from http://dx.doi.org/10.1108/09578230810863253

Harris, A. (2009). Distributed school leadership. Evidence, issues and future directions. Penrith: ACEL. 
Harris, A., Leithwood. K., Day, C., Sammons, P., \& Hopkins, D. (2007). Distributed leadership and organizational change. Reviewing the evidence. Journal of Educational Change, 8, 337-347. doi 10.1007/s10833-007-9048-4

Heikka, J. (2014). Distributed Pedagogical Leadership in Early Childhood Education. Acta Electronica Universitatis Tamperensis 1392. University of Tampere, Finland.

Heikka, J., Waniganayake, M., \& Hujala, E. (2013). Contextualising distributed leadership within early childhood education: Current understandings, research evidence and future challenges. Educational Management, Administration \& Leadership, 41(1), 30-44. doi:10.1177/1741143212462700

Ho, D. C. W. (2010). Teacher participation in curriculum and pedagogical decisions: Insights into curriculum and leadership. Educational Management, Administration and Leadership, 38, 613-624. doi:10.1177/1741143210373739

Ho, D. C. W. (2011). Identifying leadership roles for quality in early childhood education programmes. International Journal of Leadership in Education: Theory and Practice, 14(1), 47-57. doi: 10.1080/13603120903387561

Ho, D. C. W., \& Tikly, L. P. (2012). Conceptualizing teacher leadership in a Chinese, policy-driven context: A research agenda. School Effectiveness and School Improvement, 23, 401-416. doi: 10.1080/09243453.2012.678861

Hognestad, K., \& Boe, M. (2014). Knowledge development through hybrid leadership practices. Nordisk Barnehageforskning, 8(6), 1-14. Retrieved from https://journals.hioa.no/index.php/nbf/article/view/492/1074

Hognestad, K., \& Boe, M. (2015). Leading site-based knowledge development; a mission impossible? Insights from a study from Norway. In M. Waniganayake, J. Rodd, \& L. Gibbs (Eds.), Thinking and learning about leadership. Early childhood research from Australia, Finland and Norway (pp. 210-228). Sydney: Community Child Care Co-operative (NSW).

Hsieh, H. F., \& Shannon, S. E. (2005). Three approaches to qualitative content analysis. Qualitative Health Research, 15, 1277-1288. doi:10.1177/1049732305276687

Hujala, E., Waniganayake, M., \& Rodd, J. (Eds.). (2013). Researching Leadership in Early Childhood Education. Research Monograph. Tampere, Finland: Tampere University Press.

Krippendorff, K. (1980). Content analysis: An introduction to its Methodology. Beverly Hills, CA: Sage.

Leithwood, K., Mascall. B., Strauss, T., Sacks. R., Memon, N., \& Yashkina, A. (2007). Distributing leadership to make schools smarter: Taking the ego out of the system. Leadership and Policy in Schools, 6, 37-67. doi: 10.1080/15700760601091267

MacBeath, J. (2005). Leadership as distributed: A matter of practice. School Leadership and Management, 25, 349-366. Retrieved from http://search.proquest.com/docview/219025982?accountid=11739

Mascall, B., Leithwood, K., Strauss, T., \& Sacks, R. (2008). The relationship between distributed leadership and teachers' academic optimism. Journal of Educational Administration, 46, 214-228. doi 10.1108/09578230810863271

Mayring, P. (2000). Qualitative Content Analysis [28 paragraphs]. Forum Qualitative Sozialforschung / Forum: Qualitative Social Research, 1(2), Art. 20, http://nbnresolving.de/urn:nbn:de:0114-fqs0002204.

Muijs, D., \& Harris, A. (2007). Teacher leadership in (in)action: Three case studies of contrasting schools. Educational Management, Administration \& Leadership, 35, 111-134. doi: 10.1080/13634230500197165 
OECD (Organisation for Economic Co-operation and Development). (2012). Starting strong III - A quality toolbox for early childhood education and care. OECD Publishing. Retrieved from http://dx.doi.org/10.1787/9789264123564-en

Rodd, J. (2013). Leadership in Early Childhood. The pathway to professionalism. ( $^{\text {th }}$ edition). Sydney: Allen and Unwin.

Sims, M., \& Waniganayake, M. (2015). The role of staff in quality improvement in early childhood. Journal of Education and Training Studies, 3(5), 187-194. doi:10.11114/jets.v3i5.942

Smylie, M. A., \& Mayrowetz, D. (2009). Footnotes to teacher leadership. In L. J. Saha \& A. G. Dworkin (Eds.), International Handbook of Research on Teachers and Teaching (pp. 277-289). New Your, NY: Springer Science + Business Media.

Spillane, J. P., Halverson, R., \& Diamond, J. B. (2001). Investigating school leadership practice: a Distributed Perspective. Educational Researcher, 30, 23-28. Retrieved from http://edr.sagepub.com/content/30/3/23.full.pdf+html

Spillane, J. P., Halverson, R., \& Diamond, J. B. (2004). Towards theory of leadership practice: A distributed perspective. Journal of Curriculum Studies, 36, 3-34. doi:10.1080/0022027032000106726

Taguma, M., Litjens, I., \& Makowiecki, K. (2012). Quality Matters in Early Childhood Education and Care: Finland 2012. Paris: OECD.

Timperley, H. S. (2005). Distributed leadership: developing theory from practice. Journal of Curriculum Studies, 37, 395-420. doi: 10.1080/00220270500038545

Varhaiskasvatuksen henkilöstön koulutus ja osaaminen. Nykytila ja kehittämistarpeet. (2007). [Education and skills of early childhood education and care staff - the present state and development needs] Sosiaali- ja terveysministeriön selvityksiä 2007:7.

Waniganayake, M. (2015). Leading change: Issues influencing the role of educational leaders in Australia. Early Education Journal, 77, Autumn, 12-15.

Waniganayake, M. (2014). Being and becoming early childhood leaders: Reflections on leadership studies in early childhood education and the future leadership research agenda. Journal of Early Childhood Education Research, 3(1), 66-81. Retrieved from http://jecer.org/wp-content/uploads/2014/09/Waniganayake-issue3-1.pdf

Waniganayake, M., Cheeseman, S., Fenech, M., Hadley, F., \& Shepherd, W. (2012). Leadership: Contexts and complexities in Early Childhood Education. South Melbourne: Oxford University Press.

Waniganayake, M., Morda, R., \& Kapsalakis, A. (2000). Leadership in child care centers: Is it just another job? Australian Journal of Early Childhood, 25(1), January, 1-6.

Waniganayake, M., Rodd, J., \& Gibbs, L. (Eds.). (2015). Thinking and Learning about Leadership: Early childhood research from Australia, Finland and Norway. Research Monograph \#2. Sydney: Community Child Care Cooperative NSW.

York-Barr, J., \& Duke, K. (2004). What do we know about teacher leadership? Findings from two decades of scholarship. Review of Educational Research, 74, 255-316. Retrieved from http://search.proquest.com/docview/1681907150/4EF5BED9CFFC4E00PQ/3?a countid=11739 